\title{
Social Media and War on Gaza: A Battle on Virtual Space to Galvanise Support and Falsify Israel Story
}

\author{
By Hatem El Zein* \\ Ali Abusalem ${ }^{+}$
}

The development in the communication network technology has changed drastically the narration of the prolonged war in the Middle East. It has provided the militant organisations, their supporters and their enemies another platform to ignite their war on the cyberspace. Taking the rise of notorious organisations, such "The Islamic State in Iraq and Syria [or the Levant]" (ISIS or ISIL), and their online broadcasting of statements, horrified images and videos alongside a machine of supporters to recruit new fighters, this example provides an insight on the impact of social media to militant organisations. The recent fifty days of Israel war on Gaza Strip, which named by Israel "Protective Edge Operation", emphasised the ken about the role of social media during the conflict. It has become a savvy way to win the war, because the level of success is measured by wining the hearts and minds of people, and consequently to demoralise the spirit of the enemy. This paper is an endeavour to review the Palestinian's performance on social media during the war on Gaza. It intends to show the media tactics of the Palestinian militant organisations in Gaza and Gaza's sympathisers. In the context, the paper will show also the Israeli utilisation of social media to legalise bombing on Gaza.

\section{Introduction}

The use of social media has inspired many militant organisations in the Middle East, including the jihadists who utilised this medium to spread their agendas and recruit new fighters and supporters (Carter, Maher and Neumann, 2014). With the development of social networks, the conflict in Gaza Strip between the Palestinian militant organisations, led by "The Islamic Resistance Movement" (Hamas), and Israel has moved into cyberspace (Fowler, 2014). As a result of utilising virtual space by the Palestinian militant organisations, it seems that the social media platforms has turned into another war-front alongside with the military operations (Otte, 2009).

${ }^{*}$ PhD Candidate, Central Queensland University, Australia.

${ }^{\dagger}$ Adjunct Senior Lecturer, Central Queensland University, Australia. 
The recent war on Gaza in the summer of 2014 showed how social media itself has become the news when a celebrity expresses online his or her sympathy with the Palestinian civilians in Gaza (O'Regan, 2014), or when the Palestinian militant organisations falsify the Israeli army story about taking civilians as human shields (Daileda, 2014), or when the supporters of the Palestinians attack Israeli websites and media forums (Abdul-Rahman, 2014).

To provide an overall image about the utilisation of cyberspace in the war on Gaza, this paper aims to spot basically on the use of social media by both sides of the conflict: the Palestinian militant organisations, particularly Hamas, and Israel.

\section{Background}

The history of Arab-Israeli conflict reveals that the futility of Arab state media, particularly on the eve of June War in 1967 (Abo Arja, 1996). Since the mid of last century, the Palestinian militant organisations have utilised the existed media platforms to galvanise support and win the propaganda war alongside their military operations against Israel (Elkhawalda, 2009; The Palestinian Newspapers, Magazines and Bulletins Issued after the Catastrophe in Diaspora, 2011).

In a similar vein, the awareness of the role of media in war was the reason of establishing "Military Media Unit" by Hezbollah's military arm "The Islamic Resistance" in the mid of 1980s (Lamloum, 2009; Osipova, 2011). This unit played a crucial role in showing the image of "The Islamic Resistance's" fighters and Israeli soldiers in the battlefield (Harb, 2011). However, the images were broadcasted primarily via Al-Manar television, which is operated by Hezbollah (Harb, 2011).

However, the trend of utilising traditional media has lost to a certain extent its effectiveness with the emergence of electronic media. This electronic medium put a power in the hands of militant organisations and individuals to have their voice simply without using heavy machines or spending a high amount of money in the process of online broadcasting (Otte, 2009). It allows them to have their voice without passing the en route of the gatekeeper, which is existed in the traditional media outlets.

One of the first usages of online media, in the context of Arab-Israeli conflict, was in October 2000 when the on-going peace negotiation between the Palestinian Authority and Israel failed to reach an agreement. As a result of failure and then the outburst of second Intifada, Palestinian and Israeli hackers utilised the cyberspace to attack websites and other existed virtual mediums (Kuntsman and Stein, 2010).

Another historical point of utilising social media in the Arab-Israeli conflict was in July War 2006 between Hezbollah's military arm and Israel. Hezbollah's official website (www.Hizbollah.org) was shut down after facing a cyber attack (Lyme, 2009). However, the website of Hezbollah's military arm, the official website of "The Islamic Resistance" (www.moqawama.org), was 
broadcasting daily statements issued by "The Military Media Unit", the speeches of Hezbollah's Secretary-General, and news about Israeli casualties during the war. In a similar vein, the supporters of Hezbollah's and its military arm utilised social media to express their sympathy and launched a media campaign against Israel. Thus, Hezbollah was aware about the importance of social media in the war with Israel (Kuntsman and Stein, 2010).

However, Israel in its war on Gaza on the eve of January 2009 understood the media lessons from the previous war on Lebanon and utilised the online media platforms alongside the military attack on the strip (Mayfield, 2011). Although social media utilised by both sides of the conflict during the war in November 2012, the war was short. In contrast, the recent fifty days war in 2014 revealed the importance of the online platforms to militant organisations and classical armies in the same time (O'Regan, 2014). Although this paper illuminates primarily on the use of social media by the Palestinian militant organisation in Gaza Strip during the recent war with Israel, it considers as well the use of social media by the Israeli government and Israeli army in order to provide a fuller understanding about the use of the cyberspace by both sides of the conflict and ultimately to show how the Palestinian militant organisations benefited from online outlets.

\section{Theoretical Framework and Method}

Conducting a study in the field of social media requires employing a constituent theory taking into consideration the nature of this contemporary medium.

In reviewing a number of theories, particularly those related to media ownership, it seems that the agenda-setting theory is suitable to be employed in this kind of studies, because it considers the role of media owners, or operators, and their goals included the delivered messages (Scheufele and Tewksbury, 2007; Weaver, 2007). This theory is related to the production of news about a certain issue and "not information about the issue that has the effect; it is the fact that the issue has received a certain amount of processing time and attention that carries the effect" (Scheufele and Tewksbury, 2007, p. 14).

McCombs and Shaw (Quoted in Scheufele and Tewksbury, 2007) point out that this theory "refers to the idea that there is a strong correlation between the emphasis that mass media place on certain issues (e.g., based on relative placement or amount of coverage) and the importance attributed to these issues by mass audiences" (p. 11). However, the new trend of this theory considers the effect of media (Scheufele and Tewksbury, 2007). Thus, this theory aligns with social media, which provides citizens with a medium and consequently a power to communicate (Luoma-aho, 2010). In this regard, people and organisations use social media to transmit messages about a certain issue, or issues from their point of views and the messages may have an impact.

To approach the proposed question on how the Palestinian militant organisations and Israel utilised social media in the recent war on Gaza, this 
paper considers critical media/ cultural studies. Notably, the old trend in media industry was the focus on the political economy where the focus was on the processes of production and consumptions. However, the spawned communication technologies have provided an access to the Internet, which is considered a medium of various social media platforms, and allowed the citizens to be consumers and producers in the same time (Kellner, 2009).

In his argument to develop the approach critical media/ cultural studies, Kellner (2009) points out that "the media industries are a powerful institution in contemporary societies and it is essential to comprehend how they work in order to understand, act in, and transform the environment in which we live our lives" (p. 5). Thus, this approach implies that social media is powerful, because it has a transnational effect and allows the citizens and groups to have their voice.

On the other hand, the data for this paper about using social media during the recent war on Gaza are archival. The data includes articles and commentaries published in a number of newspapers and websites about the performance of the Palestinian militant organisations and Israel on the social media platforms during the war on Gaza.

Before ensuing in the analysis and explaining how both sides of the conflicts in Gaza Strip, particularly the Palestinian militant organisations, utilised the social media platforms, it seems important to identify briefly the denotation of social media and why this virtual medium has an impact during the war.

\section{What is Social Media?}

Social media is a term refers to new media platforms where the people or the users can utilise the electronic media outlets to send or broadcast audio, textual or visual messages and receive feedback from others users (Luoma-aho, 2010).

Although social media is considered a new tool for enhancing a civil society and therefore democracy through providing the voice to citizens, it can be described a medium for conversation and coordination (Shirky, 2011), or by other words for "interaction and sharing" (Luoma-aho, 2010).

\section{Social Media and Conflict}

The use of social media is not limited to the civilians and its outcomes are not limited only to the civilians as well. In this regard, Mayfield (2011) points out that social media "may have the potential to help the Armed Forces better understand the environment in which it operates. Social media may allow more agile use of information in support of operations. Moreover, they may be harnessed to help achieve unity of effort with partners in conflict. Finding 
clever and innovative ways to help achieve the desired ends may be the key to success in a continuously evolving social media environment" (p. 79).

This description of the importance of social media to armies implies that the effective utilisation of social media in the conflict may result in achieving the goal of the war, or preventing the enemy from achieving its goal.

Similarly, social media can provide a strategic medium for militant organisations in order to win other battlefields through enticing sympathy, support and demoralising the spirit of their enemies (Kuntsman and Stein, 2010; Seib, 2012).

\section{The Israeli Army and Social Media}

Israel considers social media is important to support public diplomacy (Mekouar, 2014). In its first war on Gaza Strip by the end of 2008, the Israeli army utilised social media alongside its military operation "The Cast Lead" and backed by online activists who launched blogs, such as "The Muqata" (Zeitzoff, 2011). However, the Israeli army control over Gaza Strip borders and its control over the mobile network enabled this army to monitor and filter the broadcasting of photos through the cell-phone (Daileda, 2014). To maintain its censorship, the Israeli soldiers, who joined the fighting, were not allowed to carry their mobile phones (Ward, 2009).

Thus, the Israeli army "developed a proactive information strategy, incorporating social media tools, along with enlisting the support of the Israeli online communities, to set the agenda in the media and control perceptions of the fighting. The result was that the Israelis used information effectively to preserve strategic options enabling them to achieve their objectives" (Mayfield, 2011, p. 80).

During that war on Gaza in 2008-2009, the Israeli army broadcasted on its YouTube channel "clips of surveillance and airstrikes, eager to portray its weapons as precise and show off its technological command of the battlespace" (Ward, 2009, p. 1).

The policy of the Israeli government to win the virtual space and back the army ushered a university to arm a group of students called "Help Us Win" with computers in order to access the social media platforms and tell the world the Israeli story about the war. "New immigrants were recruited by the [Israeli] Absorption Ministry to flood blogs in their native languages with "positive" talking points, while Israeli officials held an online press conference using Twitter, a "microblog" service where all messages must adhere to a strict 140 character limit" (Ward, 2009, p. 1 and 2).

Similarly to the previous 2008-2009's war on Gaza Strip, the Israeli army in its recent war in 2014, which Israel named "The Protective Edge Operation", broadcasted videos on social media about its targets in Gaza, including the tunnels used by the Palestinian militant organisations (Lotan, 2014). In addition, the Israeli government used the "Red Alert" application to warn the Israelis when the Palestinian militant organisations fire rockets on 
Israel (Harqos, 2014). Although the Israeli army and Israeli officials utilised the social media platforms during this war, particularly Twitter hash-tag to update the followers, broadcasted videos on YouTube and uploaded images on Flicker to show Israelis seeking a shelter to hide from the rockets (Fowler, 2014; O'Regan, 2014), it seems that they failed the battle on social media (Mason, 2014). In this context, the social media campaigns of the Israeli army, including the tweets of its spokesman, failed to illustrate the reason of hitting the Palestinian civilians (Mason, 2014). Furthermore, the Israeli army failed to provide proofs about casualties of Israeli civilians as a result of rockets fired by the Palestinian militant organisations on Israel (Othman, 2014a). In this regard, the Israeli ambassador to the United Nations Ron Prosor displayed a recording audio from a mobile during a meeting of Security Council in the United Nations in order to show the delegates, who were discussing the war on Gaza Strip, the impact of sirens on the Israelis due to the continuous flow of rockets fired by the Palestinian militant organisation on Israel (Kershner, 2014).

However, the Israeli failure on social media is attributed as well to other factors. One of these factors is that the broadcasted images of the killed Palestinian civilians on the social media platforms from Gaza Strip during the war led to a widespread campaign of sympathy and raised the international voices that demand Israel to stop its war (O'Regan, 2014).

After reviewing the use of the social media platforms by the Israeli army and its government during the war on Gaza Strip, the next section aims to show how the Palestinian militant organisations utilised the cyberspace during the war.

\section{Social Media and the Palestinian Guerrillas}

The war between "The Islamic Resistance" of Hezbollah and the Israeli army in 2006 provided the Palestinian militant organisations lessons about the importance of media in the conflict (Othman, 2014a).

During 2008-2009's war on Gaza Strip, Hamas has utilised the social media platforms, mainly Twitter through launching a hash-tag "QassamCount" to report "where Hamas rockets landed, when they landed, and what type of rocket was used" (Zeitzoff, 2011, p. 943). According to Jerusalem Post newspaper, it was estimated that 10,000 users signed up to display the "QassamCount" in the conflict's first three days" (Ward, 2009, p. 1). However, The Islamic Jihad Movement in Palestine opted during the war on Gaza in 2012 to send sms messages in Hebrew to the mobile phones of nearly 5000 Israeli soldiers and officers (Othman, 2014a). Similarly, Hamas used this form of hacking to communicate with the Israeli soldiers during the recent war on Gaza, penetrating the broadcasting of a number of Israeli media outlets to send messages to the Israeli public in the context of psychological warfare (Othman, 2014b) and hacking Facebook pages of some Israeli companies to broadcast warning messages (Fowler, 2014). 
The military media units of militant organisations, mainly the unit which belongs to Izz al-Din al-Qassam Brigades, Hamas' military arm, operated a number of accounts on Twitter, such as \#GazaUnderAttack, \#Gaza, \#StopIsrael, and \#PrayForGaza, to provide up-to-date news about the Palestinian casualties and news about launching rockets towards Israel (Fowler, 2014). In addition, the strategy of using social media by this militant organisation was to falsify Israel story that Hamas' fighters are using civilians as human shields and civil infrastructure, such as schools, to launch rockets towards Israel (Fowler, 2014; O'Regan, 2014). This strategy aimed as well to change the international perception about the Israeli war on Gaza Strip by broadcasting images of the injured and killed children by Israeli airstrikes (Fowler, 2014).

Notably, the \#FreePalestine hash-tag, which launched by supporters of the Palestinian cause, enticed many people around the world, including celebrities who tweeted this hash-tag to show their sympathy with the Palestinian civilians who suffer from the Israeli airstrikes (O'Regan, 2014).

To demoralise the Israeli spirit, "The Military Media Unit" of Hamas' military arm provided the combatants with new brand cameras fixed on their shoulders and heads to film their military actions in order to document them and extract suitable videos for online broadcasting after editing. Furthermore, the unit broadcasted on its website video songs in Hebrew, such as "The End of Hope", which is an opposite version of Israel anthem, and short films to document the continuous manufacturing of rockets in Hamas' factories and transporting them to the battlefield (Othman, 2014a).

The length of the recent war and the amount of destruction resulted from the Israeli army airstrikes enabled many journalists and civilians to broadcast online the shocking images of the war on Gaza Strip (Lejeune, 2014). The images and videos broadcasted on Instagram provided a visual narration on this strip (Mekouar, 2014). However, the Arab sympathisers with the Palestinians launched a media campaign against the Israeli army spokesman and urged the online users to stop following him on Twitter (Abdul-Rahman, 2014).

This support on social media to the Palestinians allowed Hamas to succeed in the cyber war. However, the question is what does this success mean?

\section{Results}

In an article published on the website of "Voice of America", Mekouar (2014) quoted words of the digital director of the Israeli embassy in the United States Jed Shein who denied that social media affected negatively the image of Israel in Washington and Europe. Furthermore, the same author of the article also quoted the words of a specialist in technology and peace-building at the United States Institute of Peace, Anand Varghese, who pointed out that the role of social media helped in humanising the consequences of the war on Gaza Strip by showing the Palestinian and Israeli victims. 
Although it is difficult to measure the level of impact or success of war on social media on the conflict, it is crucial that the broadcasted images and videos can play a role in enticing sympathy with the victims. This notion of victimisation seems the hinged point that both sides of the conflict tried to gain. Figure 1 shows the difference between the users of the hashtag \#GazaUnderAttack and the hashtag \#IsraelUnderFire during a month of the recent war on Gaza according to the social-media search engine Topsy.

Figure 1. The Users of Hastags \#GazaUnderAttack and \#IsraelUnderFire between 22 July 2014 and 21 August 2014

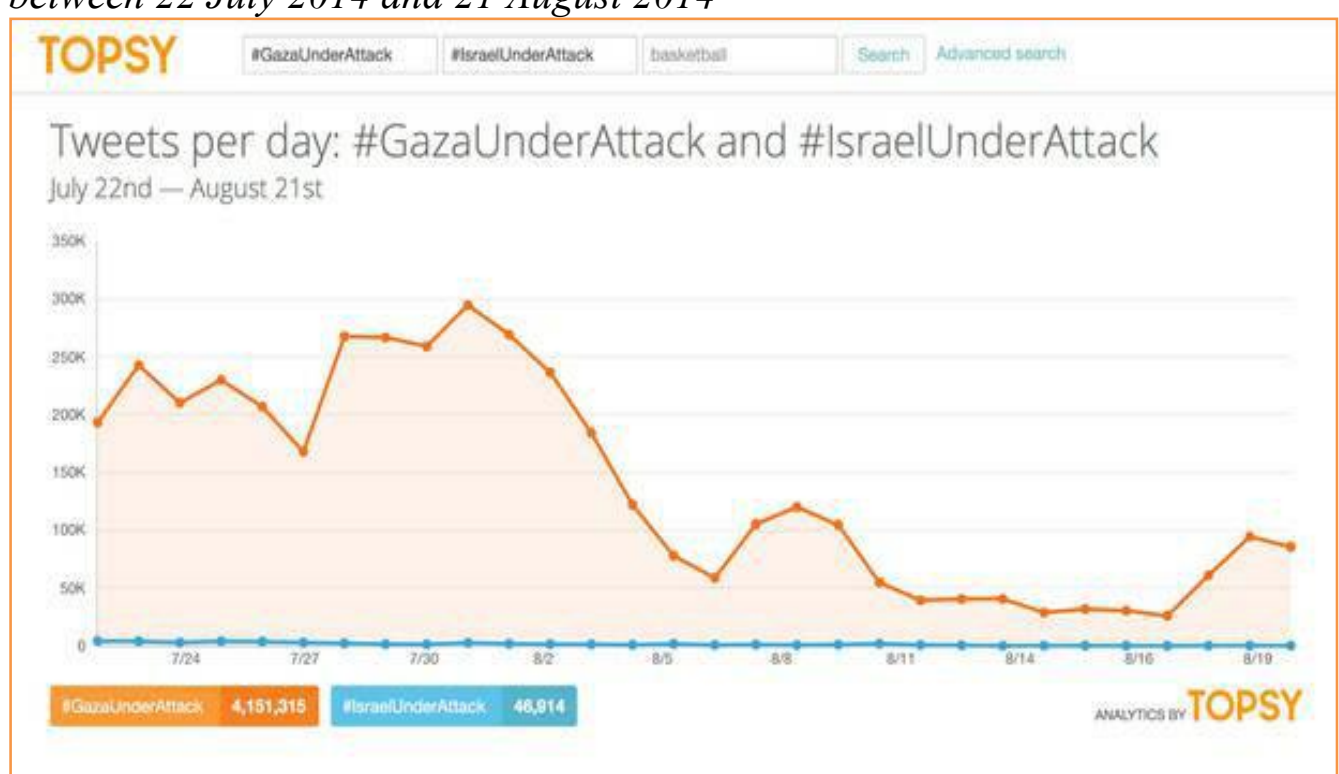

Source: Dabour, 2014

According to Figure 1, the hashtag \#GazaUnderAttack enticed a huge number of followers in comparison with the hashtag \#IsraelUnderFire.

Although social media cannot change the status quo, it is without any doubt has an impact (Seib, 2012). It seems that the accessibility to social media has changed the face of war, because it delimits the power of traditional media and allows both sides of the conflict to utilise this medium in order to legalise their actions and to describe them as defending acts. However, the scenes of blood and killed innocents are inevitable. Thus, the broadcasted images of the victims may, at least, lead to a moral condemnation around the globe and put a pressure on the international community to take actions to stop the bloodshed.

One of the lessons of the Israeli war on Gaza Strip is represented by the difficulty for any military power to have control over all means of communication in order to prevent others from broadcasting their version of the story. Thus, the Palestinian militant organisations in Gaza Strip were aware about this issue and they utilised social media to galvanise support. In this vein, they broadcasted the stories and images to say that they are victims of the occupation and to show that the Israeli army kills elderly, women and children.

As a result of utilising social media in this conflict, it seems that the recent war on Gaza can be considered a turning point for both the Palestinian militant 
organisations and Israel to revise their media strategies and tactics for any coming war.

\section{Conclusions}

This paper has shaded the light on the use of social media during the Israeli war on Gaza Strip, particularly by the Palestinian militant organisations. It outlined the importance of social media as a platform for citizens to broadcast and have their voice. Also, it showed the importance of utilisation of social media during the conflict, because it can breach the monopoly of traditional media coverage of the war diaries.

The paper reviewed the use of Israel and the Israeli army of social media in its wars on Gaza Strip. Similarly, it reviewed the use of social media by the Palestinian militant organisations. However, the focus was on the use of social media during the recent war on Gaza. In this vein, the use of Internet in the context of conflict goes back to the second Intifada and emphasised during and after Israel war on Lebanon in July War in 2006.

This paper has found out that the Palestinian militant organisations, mainly Hamas, have utilised social media to falsify the Israeli army stories about the targets in Gaza Strip and waged a psychological warfare against Israel.

In addition, the supporters of the Palestinian cause on social media succeeded in the recent war by putting pressure on Israel through showing the world the level of destruction in Gaza Strip and footages of the victims, particularly children. These actions on the virtual space urged international voices, including celebrities, to use their social media platforms to call for an immediate ceasefire, to express their sympathy with the victims, and to condemn the killing of civilians.

In this regard, this paper has discussed the impact of social media on the war on Gaza. It concluded that social media has an impact during the war, because it provides the victims the power to have their voice by showing the world their suffering and their loss of homes and beloved ones. In short, it seems that the Palestinian militant organisations have invested on the social media platforms the notion of victimisation to defeat morally the Israeli army. This investment backed directly and indirectly by the sympathy campaigns on social media with the Palestinian civilians in Gaza Strip during the war.

\section{References}

Abo Arja, T. (1996). The Arabic Media: The Current and Future Challenges (in Arabic). Amman: Dar Mejdlawi.

Abdul-Rahman, M. (2014, August 04). Unfollow [The Israeli Army Spokesman] Avichay Adraee (in Arabic), Al-Akhbar, Issue 2359, p. A32.

Carter, J. A., Maher, S., \& Neumann, P. R. (2014). \#Greenbirds: Measuring Importance and Influence in Syrian Foreign Fighter Networks. London, UK: 
King's College London, The International Centre for the Study of Radicalisation and Political Violence.

Dabour, B. (2014, August 21). In asymmetric Twitter war over Gaza, Palestinians are winning. The Electronic Intifada. Retrieved from http://electronicintifada.net/ blogs/belal-dabour/asymmetric-twitter-war-over-gaza-palestinians-are-winning

Daileda, C. (2014, July 22). Israel Is Losing Control of the Gaza Media War. Mashable. Retrieved from http://mashable.com/2014/07/22/israel-losing-mediawar-gaza/

Elkhawalda, M. N. (2009). The Radio of Palestinian Resistance (1968-1982) and its Role in Clarifying the Just Cause of Palestinian People and its Solution (in Arabic). Palestinian Information Ministry. Retrieved from http://www.minfo.ps/ arabic/index.php?pagess $=$ main\&id $=146$

Fowler, S. (2014, July 15). Hamas and Israel Step Up Cyber Battle for Hearts and Minds. $B B C$ News. Retrieved from http://www.bbc.com/news/world-middle-east28292908

Harb, Z. (2011). Channels of Resistance in Lebanon: Liberation Propaganda, Hezbollah and the Media. London, UK: I.B.Tauris.

Harqos, H. (2014, August 19). Resilience during the War: The Priority to Save Data and Communication (in Arabic), Al-Akhbar, Lebanon, Issue 2371, pp. A12-A13.

Kellner, D. (2009). Toward a Critical Media/Cultural Studies. In. R. Hammer \& D. Kellner (Eds.), Media/Cultural Studies: Critical Approaches (pp. 5-24). New York, NY: Peter Lang.

Kershner, I. (2014, July 10). Gaza Deaths Spike in 3rd Day of Air Assaults While Rockets Hit Israel. The New York Times. Retrieved from http://www.nytimes. com/2014/07/11/world/middleeast/israel-gaza.html?_r=0

Kuntsman, A. \& Stein, R. L. (2010, September). Another war zone: Social media in the Israeli-Palestinian conflict. Middle East Report Online. Retrieved from http:// www.merip.org/mero/interventions/another-war-zone

Lamloum, O. (2009). Hezbollah's Media Political History in outline. Global Media and Communication, 5(3), 353-367.

Lejeune, M. (2014, August 04). A German Testimony about the War [on Gaza] (in Arabic), Al-Akhbar, Lebanon, Issue 2359, p. A10.

Lotan, G. (2014, August 12). Israel, Gaza, War \& Data: Social Networks and the Art of Personalizing Propaganda. The Huffington Post. Retrieved from http://www. huffingtonpost.com/gilad-lotan/israel-gaza-war-social-networks-data_b_5658557 .html\#

Luoma-aho, V. (2010). Is Social Media Killing Our Theories? Paper presented at Viestinnän Tutkimuksen Päivät (Communication Research Days), University of Tampere, Finland, February 12, 2010. Retrieved from http://www.arifyildirim. com/ilt508/vilma.luoma-aho.pdf

Lyme, R. F. (2009). Hizb'allah's Communication Strategy: Making Friends and Intimidating Enemies (No. 2009: 19). DIIS Reports/Danish Institute for International Studies.

Mason, P. (2014, August 11). Truth and Propaganda: the Other Two Foes in Gaza's War. The Guardian. Retrieved from http://www.theguardian.com/commentisfree/ 2014/aug/10/truth-propaganda-foes-gaza-war-independent-journalism

Mayfield, T. D. (2011). A Commander's Strategy for Social Media. Joint Forces Quarterly 60(1), 79-83.

Mekouar, D. H. (2014, July 31). \#Gaza: Social Media Amplifies New Voice in Mideast Conflict. Voice of America. Retrieved from http://www.voanews.com/ content/gaza-social-media-amplifies-new-voice-in-mideast-conflict/1968253.html 
O’'Regan, S. V. (2014, August 01). A Battle for Hearts and Minds: Who's Winning Gaza's Social Media War? SBS. Retrieved from http://www.sbs.com.au/news/ar ticle/2014/07/17/battle-hearts-and-minds-whos-winning-gazas-social-media-war

Osipova, Y. (2011, Fall). Hizballah's Media Strategy: Creating a "Theater of Terror". Journal of International Service, 83-101.

Othman, O. (2014a, August 20). Palestine: The Resistant Media to Agitate Israel Security (in Arabic), Al-Akhbar, Issue 2372, p. A14.

Othman, O. (2014b, August 30). Between Two Intifadas and Three Wars: The Tactics Have Change (in Arabic), Al-Akhbar, Issue 2381, p. A20.

Otte, J. T. (2009, February). Cyberspace and Propaganda: Israel and the War in Gaza. $\quad$ Retrieved from http://lisd.princeton.edu/sites/lisd/files/commentary_february20 09.pdf

Scheufele, D. A., \& Tewksbury, D. (2007). Framing, Agenda Setting, and Priming: The Evolution of Three Media Effects Models. Journal of Communication 57(1), 09-20.

Seib, P. (2012). Real-Time Diplomacy: Politics and Power in the Social Media Era. New York, NY: Palgrave Macmillan.

Shirky, C. (2011). The Political Power of Social Media: Technology, the Public Sphere, and Political Change. Foreign Affairs 90(1), 28-41.

The Palestinian Newspapers, Magazines and Bulletins Issued after the Catastrophe in Diaspora. (2011). Palestinian News \& Info Agency, Retrieved from http://www. wafainfo.ps/atemplate. aspx?id=4422

Ward, W. (2009, January). Social Media in the Gaza Conflict. Arab Media \& Society. Retrieved from http://www.arabmediasociety.com/articles/downloads/20090121 104211_AMS7_Will_Ward.pdf

Weaver, D. H. (2007). Thoughts on Agenda Setting, Framing, and Priming. Journal of Communication 57(1), 142-147.

Zeitzoff, T. (2011). Using Social Media to Measure Conflict Dynamics: An Application to the 2008 -2009 Gaza Conflict. Journal of Conflict Resolution 55(6), 938-969. 
